\title{
State Digitalzation Policy as a Factor of Sustainable Inclusive Growth and Development of Russian Regions
}

\author{
Rustam Sharafutdinov ${ }^{1}$, Vladislav Gerasimov ${ }^{2}$, Elvir Akhmetshin ${ }^{3, *}$, Hilary Okagbue ${ }^{4}$, and \\ Asiyat Tagibova ${ }^{5}$ \\ ${ }^{1}$ Academy Sciences of the Republic of Tatarstan, Center of Advanced Economic Research, Karl Marx \\ st. 23/6, 420111, Kazan, Russia \\ ${ }^{2}$ Kazan Federal University, Naberezhnye Chelny Institute of KFU, 1st Complex street, 1/18, 423812 \\ Naberezhnye Chelny, Russia \\ ${ }^{3}$ Kazan Federal University, Elabuga Institute of KFU, Kazanskaya street, 89, 423604 Elabuga, Russia \\ ${ }^{4}$ Covenant University, KM 10 Idiroko Rd, Ota, Nigeria \\ ${ }^{5}$ Moscow State Institute of International Relations (MGIMO),Vernadsky Ave., 76, 119454 Moscow, \\ Russia
}

\begin{abstract}
This research paper addresses the need for digitalization of the economy in socially important areas of the Russian Federation, particularly its regions. The purpose of the study is to examine the relationship of digitalization with the processes of inclusive growth and regional development. The study identifies the main directions of the digitalization policy, its overall effectiveness, as well as those processes that make certain public goods more accessible for the population, namely: education, healthcare, security, infrastructure and their possible impact on inequality and the level of income of the population. Problems are identified in the existing national and regional digitalization policy, which is not able to ensure a steady increase in citizens' incomes, high-quality and affordable higher education, as well as reduce the social tension of the population. Based on the foregoing, the authors offer recommendations for resolving these problems in terms of a digitalization approach and an improved digitalization policy with a view to sustainable inclusive socioeconomic growth and development of the Russian Federation regions.
\end{abstract}

\section{Introduction}

Today, the innovative and technological transformation of the world has acquired global proportions and is becoming a turning point in the socio-economic development of the history of the whole world. During this transformation, there has occurred a transition from economic stagnation to a gradual steady increase in population incomes, an increase in the living standards ofsociety, and an increase in the availability of basic social and economic benefits [1]. The general accessibility of socio-economic benefits and developed

\footnotetext{
* Corresponding author:elvir@mail.ru
} 
infrastructure, due to the innovative and digitalization policies in the world, allows each year to increase the standard of living of the population and lead to equal social and economic opportunities for citizens [2]. Increasing the availability and quality of digital technologies for citizens has a significant impact on their level of awareness of both internal and external changes in the world, which increases their social mobility and the ability to acquire new knowledge and skills that are so important for the development of human capital[3, 4]. In the modern world, the availability of digital technologies is just as important for the population, as the availability of clean sources of drinking water meeting all the necessary standards, as well as the availability of modern infrastructure in the field of electricity and gas supply [5]. Based on this, the international community, in particular Russia itself, should ensure equal access to this unique and innovative resource for the population.

The development of digital technologies enables us to make goods and services ordered through digital services more accessible, which reduces their cost for all segments of the population, and also forms new digital platforms for business, which leads to a noticeable activation of inclusive processes in society $[1,6]$.

Digitalization policy in the field of creation and development of digital platforms contributes to an increase in the availability of state and municipal services in the field of medicine, finance, social security, infrastructure construction, followed by a stable increase in the living standards of the population; it helps to form a high intellectual human capital for the innovative transformation of economic systems in all spheres of people's life [7,8].

At the same time, accessibility and availability of higher education are just as important as having a digital public infrastructure [9-12]. The indicators of the level of education and incomes are closely interrelated, which has been repeatedly noted in the works of many Russian and foreign scientists. Education is one of the main forms of investment in human capital. People invest in human capital for similar reasons as in financial assets, including in order to increase their financial well-being [13]. In general, those citizens who have a higher level of education, respectively, receive higher incomes [14, 15]. Thus, the introduction of digital technologies in education in other countries allows people to accumulate and competently manage the public good, making education more accessible as well as opening equal opportunities for more citizens to increase their well-being and social status $[14,16]$.

Favorable results of digital activities can be traced in all spheres of human life: from the emergence of new forms of employment for citizens to the general increase in living standards, which is one of the main goals of inclusive growth and development $[17,18]$. The International Organization for Economic Cooperation concludes in its research that with the strengthening of the pace of digitalization policy and the creation of digital infrastructure, with the gradual and ubiquitous dissemination of digital services and technologies, in developed countries, labor productivity is much higher and more progressive than in countries with transition economies [5].

As a result of this, the economic activity of citizens can create additional GDP of $\$ 2.2$ trillion and ensure the formation of more than 140 million new jobs around the world [19].

However, despite such prospects for digitalization development, the problem of inequality in incomes and regional imbalance leads to the fact that only a limited number of people receive these benefits from digitalization policy. In addition, with the increase in the availability of some goods, the availability of other goods decreases proportionally, which is especially evident in the example of the Russian Federation, where, with an increase in the coverage of Internet technologies, real incomes of the population fall, the coverage of higher education programs through e-learning systems decreases, as well as a number of other indicators, which cannot positively affect the formation and development of human capital [20]. 
The destructive nature of such phenomena relies on the fact that the digital economy and inclusive processes can develop only with a sufficient level of literacy of the population, which has equal access to all goods and services. This is especially true for the higher education system and its infrastructure, including digital, which is the institutional basis for the effectiveness of sustainable inclusive growth and development of a region.

\section{Methods}

The works of foreign and domestic scientists and specialists in the field of digital economy and digitalization policy were used as a methodological, analytical, practical, and theoretical basis for the study. The scientific works of foreign experts in the field of sustainable inclusive economic growth and development were analyzed, which allowed us to identify and build the institutional structure of inclusive growth and development, in conjunction with the digitalization processes of the economy and improve the effectiveness of the human capital management system, which allowed us to build a structure of the relationship between inclusive growth and development with digitization in education and socio-economic infrastructure.

Based on the statistical data of the Federal State Statistics Service of Russia on the socio-economic and digital development of the Russian Federation, its regional divisions, as well as information from the ministries that are freely available and obtained in previous research results, the authors have identified and shown the current economic development situation from the point of view of digitalization policy and inclusive processes in Russia.

The main indicators of digitalization have been considered: the coverage and use of various socio-economic needs of the population and broadband Internet service companies for 2012-2018, the degree of its implementation in the structure of modern education, in particular in the higher education system, the level of development of electronic government and document management. Also, indicators of inclusive growth and development have been identified, the formation of which can be influenced by digital technologies, namely: the availability of higher education programs for the population, the availability of digital services and other socio-economic benefits. Ultimately, the work has actively used statistical, comparative and systematic methods of studying the digitalization policy of Russia in conjunction with inclusive growth and development, as well as the human capital of the region.

\section{Results}

Digitalization policy (in a regional aspect) in modern socio-economic systems refers to the process of implementing information technology in all spheres of society and economic sectors, in order to increase their efficiency and increase the availability of public goods and services.

Inclusive growth and development (in the aspect of digitalization) is a model of socioeconomic development, which includes the totality of all segments of the population, by making them accessible to basic goods and services in order to increase income and gradually equalize inequality in society. Based on the above definitions, it is obvious that the structure of the relationship between digitalization policy and inclusive growth has a clearly divided structure with elements of stratification of integral indicators (Figure 1). 
Institutional foundations of inclusive growth and development

\begin{tabular}{|c|c|c|}
\hline Equality of Opportunities & $\begin{array}{c}\text { Key infrastructure } \\
\text { facilities, including digital } \\
\text { infrastructure }\end{array}$ & $\begin{array}{c}\text { Formation and development of } \\
\text { skills }\end{array}$ \\
\hline $\begin{array}{l}\text { Fair Taxation and Social } \\
\text { Security }\end{array}$ & & Poverty and inequality \\
\hline$\frac{\text { Productive allocation of }}{\text { financial resources }}$ & & $\begin{array}{c}\text { Healthy Institutions, Business } \\
\text { and Political Ethics }\end{array}$ \\
\hline$-\cdots-\cdots-\cdots-\cdots-\cdots-\cdots-$ & $\begin{array}{l}\text { Inclusive Growth and } \\
\text { Development }\end{array}$ & $-\cdots-\cdots-\cdots-\cdots-\cdots-\cdots-$ \\
\hline $\begin{array}{l}\text { Access and quality in } \\
\text { education and health }\end{array}$ & & $\begin{array}{c}\text { Accessibility and contribution to } \\
\text { basic and digital infrastructure, } \\
\text { and public health services }\end{array}$ \\
\hline Social security system & & $\begin{array}{l}\text { Economic growth and } \\
\text { employment }\end{array}$ \\
\hline Management and institutions & Standards of living & Financial intermediation \\
\hline
\end{tabular}

Digitalization-dependent institutional foundations of inclusive growth

Italicized - strongly affected by digital technologies;

Underlined - moderately affected by digital technologies;

Semi-bold - difficult to affect by digital technologies;

Fig. 1.The structure of inclusive growth and development in conjunction with digitalization.

From this scheme it becomes obvious that the most powerful influence of digitalization policy is on the services, education and socio-economic infrastructure sectors.

The current digitalization policy, as well as its provisions and levels of economic development, play a crucial role in the formation of an innovative digital industry. For this reason, in the Russian Federation there have been significant changes in the socio-economic strategy for the development of the country, with the aim of the country to enter a new era of digital technology and transformation. Thanks to the country's new socio-economic strategy, the Digital Economy of the Russian Federation program has been formed, which has moved to a new level of national scale, which has taken more than 5 years of in-depth analysis of socio-economic processes, where the main result is a clear definition of the main vectors of digitalization policy [21]. The main strategic objective of this concept is a socioeconomic breakthrough in improving the quality of life of citizens and incomes of the population, by obtaining funds from the use of digital technologies, as well as modernizing the economy and introducing innovative technological products, improving infrastructure and public administration. All these transformations are necessary to strengthen Russia's position at the international level (Table 1). 
Table 1. Key indicators of the digitalization policy and institutional foundations of inclusive growth and development, average values for Russian regions

\begin{tabular}{|l|c|c|c|c|c|c|c|}
\hline \multicolumn{1}{|c|}{ Indicator } & \multicolumn{7}{|c|}{ Values by years } \\
\cline { 2 - 9 } & 2012 & 2013 & 2014 & 2015 & 2016 & 2017 & 2018 \\
\hline $\begin{array}{l}\text { The proportion of the employed population } \\
\text { aged 25 to 64 years with higher education in } \\
\text { the total employed population of the } \\
\text { corresponding age group }\end{array}$ & 30.7 & 31.2 & 32.6 & 33.0 & 33.8 & 34.3 & 35.1 \\
\hline $\begin{array}{l}\text { The number of students enrolled in } \\
\text { educational programs of higher education - } \\
\text { undergraduate, specialty, master's programs, } \\
\text { per 10,000 people }\end{array}$ & 454 & 424 & 394 & 356 & 325 & 300 & 289 \\
\hline $\begin{array}{l}\text { The number of mobile broadband Internet } \\
\text { subscribers per 100 population }\end{array}$ & 47.8 & 63.6 & 59.8 & 64.5 & 68.1 & 71.1 & 79.9 \\
\hline $\begin{array}{l}\text { Percentage of organizations using the Internet } \\
\text { in the total number of organizations surveyed }\end{array}$ & 84.8 & 86.9 & 88.1 & 89.0 & 88.1 & 88.7 & 88.9 \\
\hline $\begin{array}{l}\text { The proportion of the population that used the } \\
\text { Internet to order goods and (or) services, in } \\
\text { the total population }\end{array}$ & 11.2 & 12.3 & 15.3 & 17.8 & 19.6 & 23.1 & 29.1 \\
\hline $\begin{array}{l}\text { Percentage of households with Internet access } \\
\text { from a home computer, in the total number of } \\
\text { households }\end{array}$ & 50.2 & 59.1 & 65.1 & 67.0 & 68.4 & 70.3 & 70.3 \\
\hline Coverage with higher education programs, $\%$ & 53 & 49 & 43 & 37 & 34 & 33 & 31 \\
\hline $\begin{array}{l}\text { The proportion of the number of children } \\
\text { receiving supplementary education services } \\
\text { in the total number of children aged 5 to 18 } \\
\text { years,\% }\end{array}$ & 58.8 & 55.7 & 61.4 & 59.5 & 55.6 & 57.6 & 59.1 \\
\hline $\begin{array}{l}\text { The ratio of the average cost of higher } \\
\text { education (rubles) to the average per capita } \\
\text { cash income (state institutions) }\end{array}$ & 2.47 & 2.54 & 2.48 & 2.59 & 2.82 & 3.17 & 3.60 \\
\hline $\begin{array}{l}\text { The average cost of 1 year of study in higher } \\
\text { education programs, thousand rubles }\end{array}$ & 59.3 & 66.3 & 74.9 & 83.6 & 91.4 & 100.4 & 116.8 \\
\hline $\begin{array}{l}\text { Average per capita cash income of the } \\
\text { population, thousand rubles }\end{array}$ & 24.3 & 26.2 & 29.8 & 32.1 & 32.6 & 31.7 & 32.7 \\
\hline
\end{tabular}

Based on the data shown in table 1, it becomes obvious that there has been a wide introduction of Internet technologies in the lives of citizens, including the development of digital infrastructure. It is worth noting that with the active introduction of digitalization technologies, there is an increase in the availability of only a number of indicators, while higher education enrollment, due to its rise in price and other common problems, has negative trends in the development of the human capital management system in the region due to the lack of real income growth among the population, which certainly contradicts the concept of digitalization policy of socio-economic development of the Russian Federation. Moreover, the most expensive training programs are those closely related to digital technologies. However, in spite of the negative socio-economic indicators in the new digitalization policy of Russia, the need of employers for professionals with high competencies on the basis of high-quality higher education is growing [22]. In addition, it is worth noting that there are positive trends in the form of wide development and application of digital technologies and basic infrastructure in health care, in state and municipal departments that provide services to the population and a number of other socially and economically important areas where there is a close interaction between the state and citizens.

To answer the existing challenges, one of the most effective solutions, in the framework of the digitalization policy, is the transformation and modernization of those areas of the population activity that are most dependent on the direct impact of the human factor, namely: access to education, further coverage of all citizens by digital services and products 
and the general social and economic development of citizens and the activation of inclusive processes.

\section{Discussions}

As noted earlier, investment policy in the field of education leads to an increase in the income level of citizens, which further contributes to the sustainable formation of inclusive processes in society, which is especially noticeable in the United States of America. Longterm studies show [23] that the beneficial effect of having a higher education tends to increase over the years, but only with its systematic application and development (courses, extended education, and so on). In addition, the more different skills a person uses, the more he is adapted to work in constantly changing information and technological transformations in the world [23, 24] (Table 2).

Table 2.Relationship between education level andhousehold income in the USA [23]

\begin{tabular}{|c|c|c|c|c|c|}
\hline Education* & $\begin{array}{c}\text { Percentage } \\
\text { of families }\end{array}$ & $\begin{array}{c}\text { Median } \\
\text { income }\end{array}$ & $\begin{array}{c}\text { Median } \\
\text { wealth }\end{array}$ & $\begin{array}{c}\text { Wealth-to- } \\
\text { income } \\
\text { ratio** }\end{array}$ & $\begin{array}{c}\text { Millionaires } \\
\text { family } \\
\text { wealth })\end{array}$ \\
\hline $\begin{array}{c}\text { No high school } \\
\text { diploma }\end{array}$ & $12 \%$ & $\$ 22,320$ & $\$ 37,766$ & 1.43 & 1 in 110 \\
\hline $\begin{array}{c}\text { High school } \\
\text { diploma }\end{array}$ & $50 \%$ & $\$ 41,190$ & $\$ 95,072$ & 2.15 & 1 in 18 \\
\hline $\begin{array}{c}\text { Two- or four-year } \\
\text { degree }\end{array}$ & $25 \%$ & $\$ 76,293$ & $\$ 273,488$ & 3.45 & 1 in 4,6 \\
\hline Advanced degree & $13 \%$ & $\$ 116,265$ & $\$ 689,100$ & 5.58 & 1 in 2,6 \\
\hline
\end{tabular}

* Based on the level of education of a family headed by someone aged 40 or older.

** This ratio shows how much wealth each group has per dollar of income. For example, the coefficient for families without higher education was 1.43 , which means that, on average, 1.43 dollars of wealth came for every 1 dollar of income. This ratio is a measure of how efficiently people turn income into wealth [23].

Based on the data in table 2, it follows that higher incomes due to the availability of higher education allow to accumulate more tangible and intangible savings, so necessary for creating well-being in society [14, 23].

Similar results were shown in studies by Indian scientists who conducted more than 20 sample household surveys in the 15 largest states of India $[16,25,26]$. The results showed that the lack of basic, and in the future, vocational education, in addition to other basic factors in the development of human capital, acts as a barrier for the poor aspiring to participate in their country's production capabilities for their own socio-economic growth and development [14, 27].

An obvious fact is that the declining level of population enrollment in higher education and its accessibility requires special control. A growing problem of lack of higher education accessibility in Russia is one of the main problems in pursuing the digitalization policy, since the quality of education directly affects the number of effective solutions. Therefore, the digital transformation of universities should contribute to a significant increase in the future inclusive processes, both in the country and in its regions [28].

Due to the more and more frequent cases of liquidation of higher educational institutions in recent years, a monopoly is formed on the pricing of educational services in state universities of the country, which has an extremely negative effect on the transformation of higher education [20]. Today, the possibility of a virtual visit to lecture classes can reduce the cost of education and give priority to practical classes rather than 
theoretical writing of lectures, which is especially important in applied professions [8]. This solution will increase university capacities by creating electronic laboratories without creating physical facilities (Figure 2).

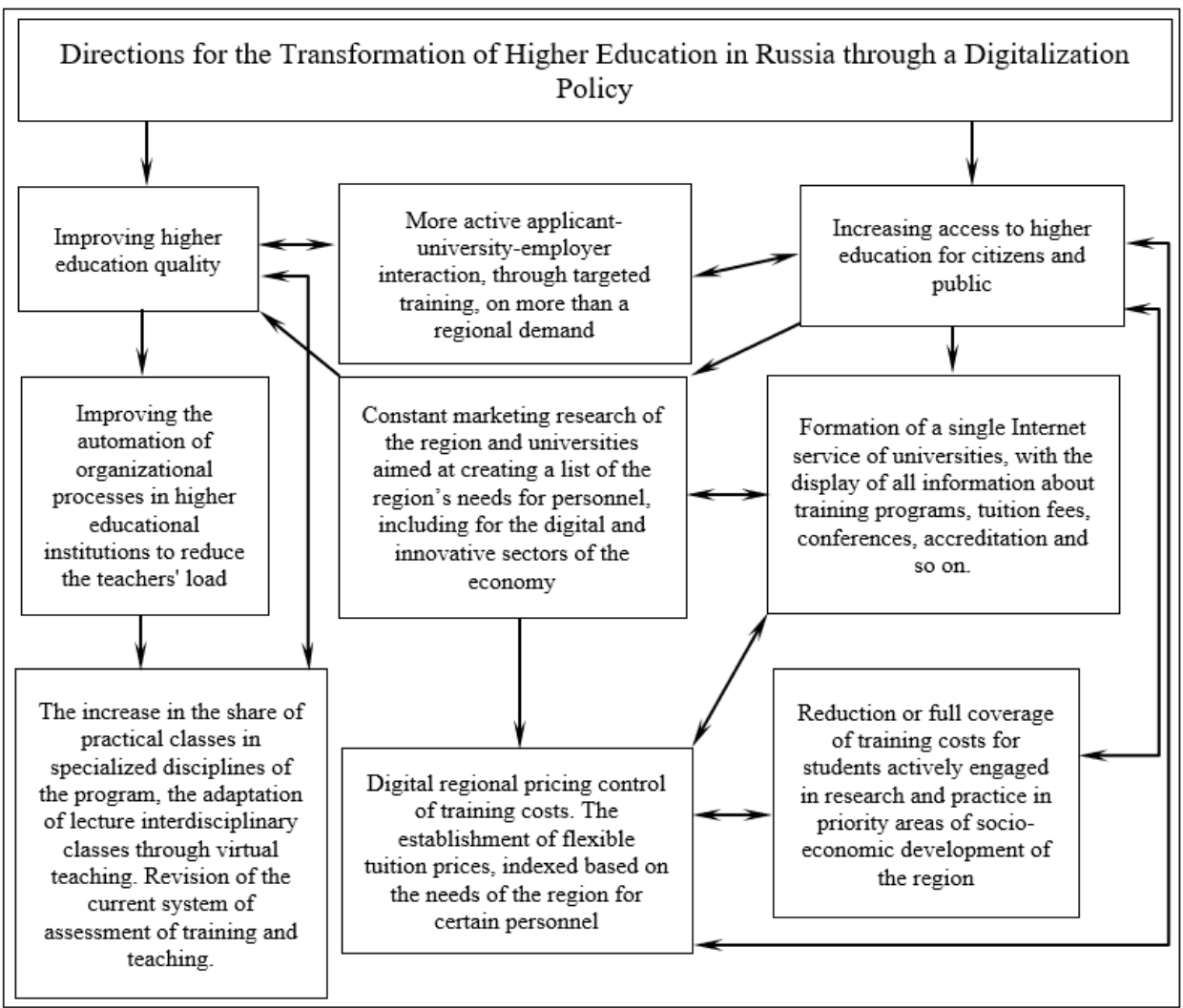

Fig. 2.Digitalization model of higher education system in Russia within the framework of sustainable inclusive growth and regional development.

This transformation model will increase the overall accessibility of higher education for more citizens, and will relieve teachers from the bureaucracy, allowing them to focus on teaching.

Basic services and digital infrastructure, within the framework of sustainable inclusive growth and development, are also important in the digitalization policy of the region. Talking about basic services and digital infrastructure, there is a very noticeable regional inequality in the Russian Federation and its regions. This inequality is expressed in the fact that regions and cities of regional significance are noticeably more developed than the outskirts, which certainly leads to an outflow of the population from the latter [15]. Studies by foreign scientists on this issue show that the influence of infrastructure variables on the indicator of consumption inequality indicates that infrastructure components, mainly energy, roads, digital technologies, the housing and communal services and waste management systems, tend to increase interpersonal inequality at the regional level, with their centralization, which is important for countries with low incomes, such as Russia. This trend is also observed in the digitalization of regions, with some regions having $4 \mathrm{G}$ networks, while others do not even have $3 \mathrm{G}[25,26]$. With a more developed road network, basic and network infrastructure, production opportunities could be provided to those who had not had access before, but the benefits from them might have increased even more for 
the already rich in terms of better investment opportunities, which led to even more high incomes, and hence to greater inequality in consumption [25-27]. This rule has almost no effect on high-income countries, with practically uniform strengthening of regions having several large centers [9].

Thus, we can conclude that the expansion of regional basic and digital infrastructure facilities can help increase the average consumption level and income increase among various segments of the population. However, these consequences are not the same for the entire population and are accompanied by increased inequality within the state, with incorrect state and regional policies [2]. In this case, the development model of the Russian Federation and its regions through the digitalization policy should take the following form (Figure 3):

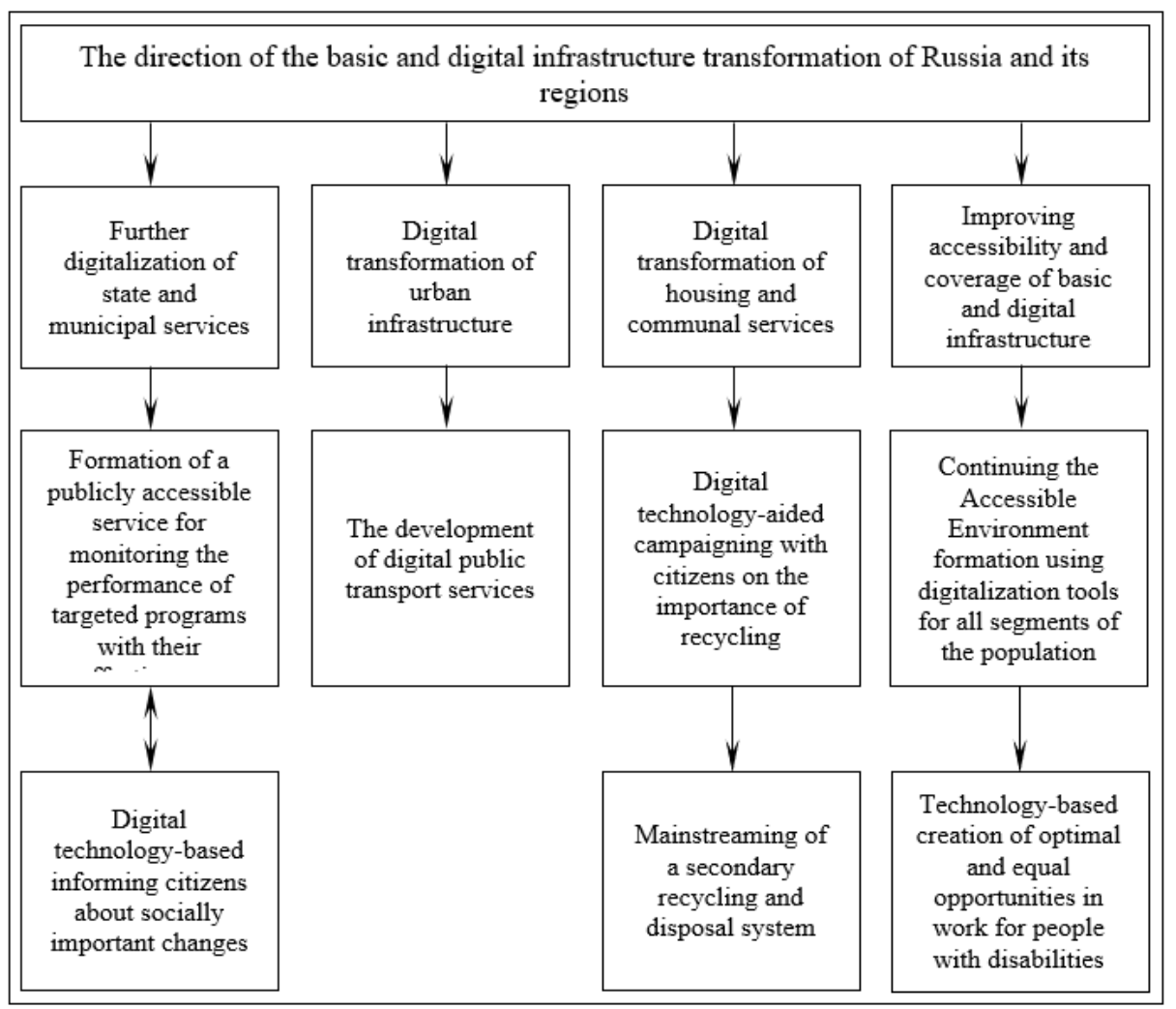

Fig. 3. Digitalization model of the basic and digital infrastructure of Russia and its regions in the framework of sustainable inclusive growth and development of regions.

Further development of the smart city system, electronic services, government, electronic document management, which allows freeing up significant time for citizens to do more important things [29]. Development of taxi and public transport system, increasing its mobility, reducing road traffic and creating an accessible environment for all citizens.

\section{Conclusions}

In the digital economy of the Russian Federation, there is a "missing political discussion" regarding the new digitalization policy and what impact this policy can have on inclusive processes in the development of Russian regions [30, 31]. Ignoring this problem does not 
contribute to progress in the socio-economic spheres of the country and inhibits the selection of the necessary steps to achieve the goals in the strategic development of the Russian Federation [4]. In order to avoid reducing the effectiveness of existing socioeconomic programs for the development of regions and to promote the digital growth of the industry, it is necessary to clearly formulate and supplement the new state digitalization policy aimed at expanding the possibilities of interaction in public-private partnerships, including in the field of digital innovations, aimed at the integration and automation of data, as well as new technological processes in the existing economic system of the state, to invest in training and education of students, in order to build skills and abilities to conduct research and innovation activities, contributing to the development of digital thinking, gradually increasing the access to the digital infrastructure of the country [18].

The formation of inclusive processes of growth and development in the Russian Federation, in particular its regions through the methods of digitalization policy, will act as the main driver for the transition of the domestic economy to a socio-economically developed state based on a powerful system of human capital management and fair distribution of benefits, which will certainly have positive impact on the development of a socially responsible state with a powerful national socio-economic system.

\section{Acknowledgements}

This work was supported by the publication activity grant scheme of the Center for Advanced Economic Research in the Academy of Sciences of the Republic of Tatarstan.

\section{References}

1. R. I. Sharafutdinov, E. M. Akhmetshin, A. G. Polyakova, V. O. Gerasimov, R. N. Shpakova, M. V. Mikhailova, Data in Brief, 23 (2019)

2. K. Mukhtarova, S. Kupeshova, S. Ziyadin, R. Doszhan. Economic Annals-XXI, 168 (11), 38 (2017)

3. B.D. Canlas, Philippine Institute for Development Studies, Discussion paper, 2, 17 (2016)

4. R.N. Takhaviev, L.N. Safiullin,International Youth Symposium on Management, Economics and Finance a collection of scientific articles, 345 (2016)

5. R.I.Sharafutdinov, V. O. Gerasimov. In the collection: Prospects for socio-economic development in the XXI century: innovative, financial, informational and legal aspects, Collection of scientific papers of the International scientific-practical conference, 199 (2019)

6. M. Muhleisen. Finance \& Development, 2(55), 1 (2018)

7. K. Arthurson. Urban Policy and Research, 20(3), 245 (2002)

8. V. O. Gerasimov, R. I. Sharafutdinov, V. V. Kolmakov, E. A. Erzinkyan, A. A. Adamenko, A. G. Vasilyeva. Entrepreneurship and Sustainability Issues, 7(2), 1074 (2019)

9. E. Hooper, S. Peters, P. Pintus, The Causal Effect of Infrastructure Investments on Income Inequality: Evidence from US States, Working paper, 1, 1 (2018)

10. V. Maltese, Cataloging and Classification Quarterly, 56(7), 592 (2018)

11. N. Vasetskaya, V. Glukhov, The Transformation of Universities in Conditions of Digitalization of National Economy. Paper presented at the Proceedings of the 33rd 
International Business Information Management Association Conference, IBIMA 2019 - Education Excellence and Innovation Management through Vision 2020, 8845 (2019)

12. O. Korableva, T. Durand, O. Kalimullina, I. Stepanova. Studying user satisfaction with the MOOC platform interfaces using the example of Coursera and open education platforms. Paper presented at the ACM International Conference Proceeding Series, 26(2019)

13. A. Pukhova, T. Belyaeva, S. Tolkunova, A. Kurbatova, L. Bikteeva, O. Shimanskaya, Journal of Entrepreneurship Education, 20(3), 1 (2017)

14. S. A. Wolla, J. Sullivan. "Education, Income, and Wealth," Page One Economics, Federal Reserve Bank of St. Louis, 1 (2017)

15. M. Feshari, M. Valibeigi, Regional Science Inquiry, 9(1), 167 (2017)

16. D.R. Ibrahim, O.I. Kazeem, A.A. Abdulfatai,Economic Change and Restructuring, 51, 29 (2018)

17. V. M. Ariadna, Dossier: the digital economy, 34 (2015)

18. E. V. Savoskina, V. V. Kapmar, Collection of articles of the International scientificpractical conference, 415 (2017)

19. Achieving inclusive growth in the face of digital transformation and the future of work, OECD report to G-20 Finance Ministers, 1 (2018)

20. B. K. Madhuri. International conference on science, Technology and management, 412 (2017)

21. Program "Digital Economy of the Russian Federation" (2017). Approved by order of the Government of the Russian Federation of July 28, 2017 No. 1632-r (2017, July 28). Government.ru, http://pravo.gov.ru/

22. S. Ziyadin, S. Suieubayeva, A. Utegenova, Lecture Notes in Networks and Systems, 84, 408 (2020)

23. R. Boshara, W.R. Emmons, B. Noeth, "The Demographics of Wealth: How Age, Education and Race Separate Thrivers from Strugglers in Today's Economy." Essay No. 2: Education and Wealth, Federal Reserve Bank of St. Louis, 4 (2015)

24. O. Hellevik, Acta Sociologica, 40(4), 377 (1997)

25. S. Bajar, M. Rajeev, Journal of Comparative Asian Development, 15(1), 122 (2016)

26. S. Bajar, M. Rajeev, The Impact of Infrastructure Provisioning on Inequality: Evidence from India (2015), http://www.global-labour-university.org/

27. D. Gaurav, M. Ravallion, Journal of Economic Perspectives, 16(3), 89 (2002)

28. H. Mahmood, N.S. Alkahtani, Economic Annals-XXI, 169(1), 31, (2018)

29. O. Korableva, O. Kalimullina, E. Kurbanova, Building the monitoring systems for complex distributed systems: Problems \& solutions. Paper presented at the ICEIS 2017 - Proceedings of the 19th International Conference on Enterprise Information Systems, 2, 221 (2017)

30. A. G. Polyakova, M. P. Loginov, A. I. Serebrennikova, E. I. Thalassinos, International Journal of Economics and Business Administration, 7(1), 130 (2019)

31. S. Ziyadin, B. Ermekbaeva, G. Supugaliyeva, R. Doszhan. Transformation of basic indicators of socio-economic processes in the digital economy. Paper presented at the Proceedings of the 31st International Business Information Management Association Conference, IBIMA 2018: Innovation Management and Education Excellence through Vision 2020, 2009-2017 (2018) 